\title{
Tick-borne pathogens in ticks collected from dogs, Latvia, 2011-2016
}

\author{
Agne Namina', Valentina Capligina', Maija Seleznova', Rudolfs Krumins' ${ }^{1}$ Darja Aleinikova', Agnija Kivrane', \\ Sarmite Akopjana ${ }^{1}$, Marija Lazovska', Inese Berzina ${ }^{2}$ and Renate Ranka ${ }^{1 *}$ (i)
}

\begin{abstract}
Background: Different tick species are able to transmit different pathogens, and tick-borne diseases are of substantial concern worldwide for both humans and animals. Environmental changes and changes in the range of tick species, including Dermacentor reticulatus in Europe, can affect the spread of zoonotic pathogens. The aim of this study was to investigate the prevalence of the tick-borne pathogens in ticks removed from dogs in Latvia, and to explore possible changes between years 2011 and 2016.
\end{abstract}

Results: In 2011, only Ixodes ticks (221 Ixodes ricinus and 22 Ixodes persulcatus) were collected from dogs, while in 2016 tick samples belonged to Ixodes ricinus (360), Ixodes persulcatus (2) and Dermacentor reticulatus (27) species. In total, 35.8 and $40.0 \%$ of adult ticks were pathogen-positive in 2011 and 2016, respectively; the difference was not statistically significant $(P>0.05)$. The molecular analysis indicated the presence of 13 tick-borne microorganisms; the most prevalent pathogen was Rickettsia, followed by Borrelia burgdorferi sensu lato group spirochetes, Anaplasma phagocytophilum and Babesia species. Borrelia miyamotoi was also present. A co-infection with two and three tick-borne pathogens was detected in 7.9 and $7.4 \%$ of Ixodes ricinus and Dermacentor reticulatus, respectively. The results of this study confirmed that the spread of novel vectors could bring additional risk of exposure to novel emerging pathogens to pets and their owners, as both Babesia canis and Rickettsia raoultii were shown to be highly associated with Dermacentor reticulatus ticks in Latvia.

Conclusions: This study demonstrates the potential danger from the inadvertent introduction of novel disease pathogens and vectors. Awareness of co-infections and Dermacentor reticulatus-related pathogens needs to be increased.

Keywords: Tick-borne pathogens, Ixodes, Dermacentor, Ticks, Dogs, Latvia

\section{Background}

Ticks are able to transmit numerous disease agents such as viruses, bacteria and protozoa, and tick-borne diseases are of substantial concern worldwide for both humans and animals. Different tick species are able to transmit different diseases, and vector competence depends on genetic determinants affecting the ability of a vector to transmit a pathogen [1]. The widespread European tick species Ixodes ricinus (I. ricinus) acts as a vector for a large variety of pathogens of medical and veterinary importance including Borrelia burgdorferi sensu lato (B. burgdorferi s.l.), tick-borne encephalitis virus, Anaplasma phagocytophilum (A. phagocytophilum), Francisella tularensis,

\footnotetext{
* Correspondence: renate_r@biomed.lu.lv

${ }^{1}$ Latvian Biomedical Research and Study Centre, Ratsupites Str. 1, Riga LV-1067, Latvia

Full list of author information is available at the end of the article
}

Rickettsia helvetica (R. helvetica), R. monacensis, Babesia divergens (B. divergens) and Babesia microti (B. microti), while the meadow or ornate dog tick Dermacentor reticulatus ( $D$. reticulatus) is an important vector for $R$. raoultii, R. slovaca, Babesia canis (B. canis), Babesia caballi, Theileria equi, Anaplasma marginale, and the brown dog tick Rhipicephalus sanguineus - for Babesia vogeli and Rickettsiales in the Mediterranean region [2-5]. The taiga tick Ixodes persulcatus (I. persulcatus), which is found in eastern Europe, northern Asia and, recently, has expanded to Finland and northern Sweden, transmits a wide range of human and animal pathogens including tick-borne encephalitis virus, B. burgdorferi s.l., Ehrlichia muris, B. microti and A. phagocytophilum [6, 7].

Dogs are hosts of several species of ticks, and surveillance of ticks and tick-borne pathogens is undoubtedly important in order to monitor the distribution of both 
vectors and tick-borne diseases. In addition, it helps to raise awareness of tick-borne diseases in dog owners, who could be ignorant of the tick-borne pathogenassociated risks to their pets. On the other hand, the recent study has showed, that pet owners, whether of cats or dogs, are at increased risk of developing tick-borne disease [8]. Subclinically infected companion animals could provide a reservoir for human tick-transmitted infectious agents, and the importance of a One Health approach was emphasized, calling physicians and veterinarians to unify their efforts in the management of tickborne zoonoses $[9,10]$.

Tick-borne diseases in Latvia, a Baltic state in Northern Europe, has been a major human health concern for many years and in the last decade has gained importance in the veterinary field as well. Up until last decade only two epidemiologically-important tick species $-I$. ricinus and I. persulcatus - were present in Latvia, but the appearance and spread of $D$. reticulatus populations and reported local clinical cases of canine babesiosis have raised concerns over the risks to pets posed by vectorborne diseases $[11,12]$. The aim of this study was to investigate the prevalence of the tick-borne pathogen species in ticks removed from dogs in Latvia, and to explore possible changes between years 2011 and 2016.

\section{Results}

Overall, 632 adult ticks from dogs were analyzed (Table 1). The mean intensity of the infestation in animals was 2.76 ( 243 ticks $/ 88$ dogs; median $=1$; range: $1-32$ ticks $)$ and 2.08 (389 ticks/187 dogs; median $=1$; range: $1-42$ ticks) in years 2011 and 2016, respectively; this difference was not statistically significant ( $P$ value $=0.0609)$. As was expected, two Ixodes tick species were identified, i.e. I. ricinus and I. persulcatus. No Dermacentor ticks were present among 243 samples collected in year 2011, however, in 2016, almost $7 \%$ of ticks removed from dogs in different regions of Latvia were $D$. reticulatus (27/389). This increase was statistically significant $(P<0.0001) . D$. reticulatus ticks were obtained in western, southern and central parts of Latvia, including Rīga, Liepāja, Daugavpils, Krāslava, Aizkraukle, Ogre and Dobele regions (Fig. 1). This result indicates that sympatric populations of $D$. reticulatus and $I$. ricinus ticks, as well as D. reticulatus, I. ricinus and I. persulcatus ticks, exist in several regions of Latvia.

Further, the prevalence of different pathogens in ticks was compared for years 2011 and 2016. In total, 35.8\% $(87 / 243)$ and $40.0 \%(155 / 389)$ of ticks removed from dogs were pathogen-positive in years 2011 and 2016, respectively; the difference was not statistically significant $(P>0.05)$ (Table 1$)$. When the prevalence of different pathogens was compared for the years studied, no statistically significant differences were observed. Most frequently, Rickettsia sp. was detected in tick samples; in total, 20.1 and $24.4 \%$ of ticks were Rickettsia-positive in years 2011 and 2016, respectively. B. burgdorferi s.l. group spirochaetes were detected in 12.8 and $8.0 \%$, and A. phagocytophilum - in 4.1 and $6.4 \%$ of tick samples in years 2011 and 2016, respectively (Table 1). The prevalence of Babesia was slightly higher for the year 2016 (5.4\% vs $2.5 \%)$, however, again, statistical significance was not reached. Importantly, for a considerable portion of the ticks removed from dogs the presence of two or three pathogens was shown; the total coinfection rate was $9.1 \%(22 / 243)$ in year 2011 , and $6.7 \%(26 / 389)$ in year 2016; again, this difference was not statistically significant $(P>0.05)$.

The molecular analysis indicated the presence of 13 tick-borne microorganisms in I. ricinus ticks: Borrelia garinii, Borrelia afzelii, Borrelia valaisiana, Borrelia spielmanii, Borrelia miyamotoi, A. phagocytophilum, B. canis, B. microti, Babesia venatorum, Babesia capreoli, $R$. helvetica, $R$. monacensis and $R$. raoultii. In D. reticulatus ticks, only two pathogens, B. canis and $R$. raoulti,

Table 1 Prevalence of pathogens in ticks from Latvian domestic dogs in years 2011 and 2016

\begin{tabular}{|c|c|c|c|c|c|c|c|c|c|}
\hline & \multicolumn{4}{|l|}{ Year 2011} & \multicolumn{5}{|l|}{ Year 2016} \\
\hline & $\begin{array}{l}\text { I. ricinus } \\
(95 \% \mathrm{Cl})\end{array}$ & $\begin{array}{l}\text { l. persulcatus } \\
(95 \% \mathrm{Cl})\end{array}$ & $\begin{array}{l}\text { D. reticulatus } \\
(95 \% \mathrm{Cl})\end{array}$ & $\begin{array}{l}\text { Total } \\
(95 \% \mathrm{Cl})\end{array}$ & $\begin{array}{l}\text { I. ricinus } \\
(95 \% \mathrm{Cl})\end{array}$ & $\begin{array}{l}\text { 1. persulcatus } \\
(95 \% \mathrm{Cl})\end{array}$ & $\begin{array}{l}\text { D. reticulatus } \\
(95 \% \mathrm{Cl})\end{array}$ & $\begin{array}{l}\text { Total } \\
(95 \% \text { Cl) }\end{array}$ & $\begin{array}{l}P \\
\text { valuet }\end{array}$ \\
\hline Ticks analysed & 221 & 22 & 0 & 243 & 360 & 2 & 27 & 389 & \\
\hline $\begin{array}{l}\text { Pathogen-positive } \\
\text { ticks* }\end{array}$ & 38.4 (32.29-45.02) & $9.0(1.34-29)$ & - & $35.8(30.03-42.01)$ & $41.7(36.69-46.82)$ & $0(0-70.98)$ & $18.5(7.72-37.16)$ & $40.0(35.10-44.79)$ & 0.3144 \\
\hline $\begin{array}{l}\text { B. burgdorferi s.l. } \\
\text { group }\end{array}$ & $14.0(10.02-19.26)$ & $0(0-17.55)$ & - & $12.8(9.1-17.58)$ & $8.6(6.1-12)$ & $0(0-70.98)$ & $0(0-14.76)$ & $8.0(5.64-11.12)$ & 0.0547 \\
\hline B. miyamotoi & $0.5(0.01-2.78)$ & $0(0-17.55)$ & - & $0.4(0.01-2.53)$ & $1.4(0.5-3.31)$ & $0(0-70.98)$ & $0(0-14.76)$ & $1.3(0.46-3.06)$ & 0.4143 \\
\hline A. phagocytophilum & $4.5(2.37-8.23)$ & $0(0-17.55)$ & - & $4.1(2.15-7.5)$ & $6.9(4.71-10.09)$ & $0(0-70.98)$ & $0(0-14.76)$ & $6.4(4.35-9.35)$ & 0.2835 \\
\hline Babesia & $2.7(1.11-5.93)$ & $0(0-17.55)$ & - & $2.5(1.01-5.41)$ & $4.7(2.92-7.48)$ & $0(0-70.98)$ & $14.8(5.3-33.1)$ & $5.4(3.52-8.15)$ & 0.1044 \\
\hline Rickettsia & $22.2(17.18-28.12)$ & $9.0(1.34-29)$ & - & $20.1(16.32-26.56)$ & $25.6(21.32-30.31)$ & $0(0-70.98)$ & $11.1(3.03-28.88)$ & $24.4(20.41-28.93)$ & 0.3335 \\
\hline Coinfections $\neq$ & $10.0(6.61-14.67)$ & $0(0-17.55)$ & - & $9.1(6-13.38)$ & $6.7(4.48-9.77)$ & $0(0-70.98)$ & $7.4(0.96-24.47)$ & $6.7(4.57-9.65)$ & 0.2833 \\
\hline
\end{tabular}




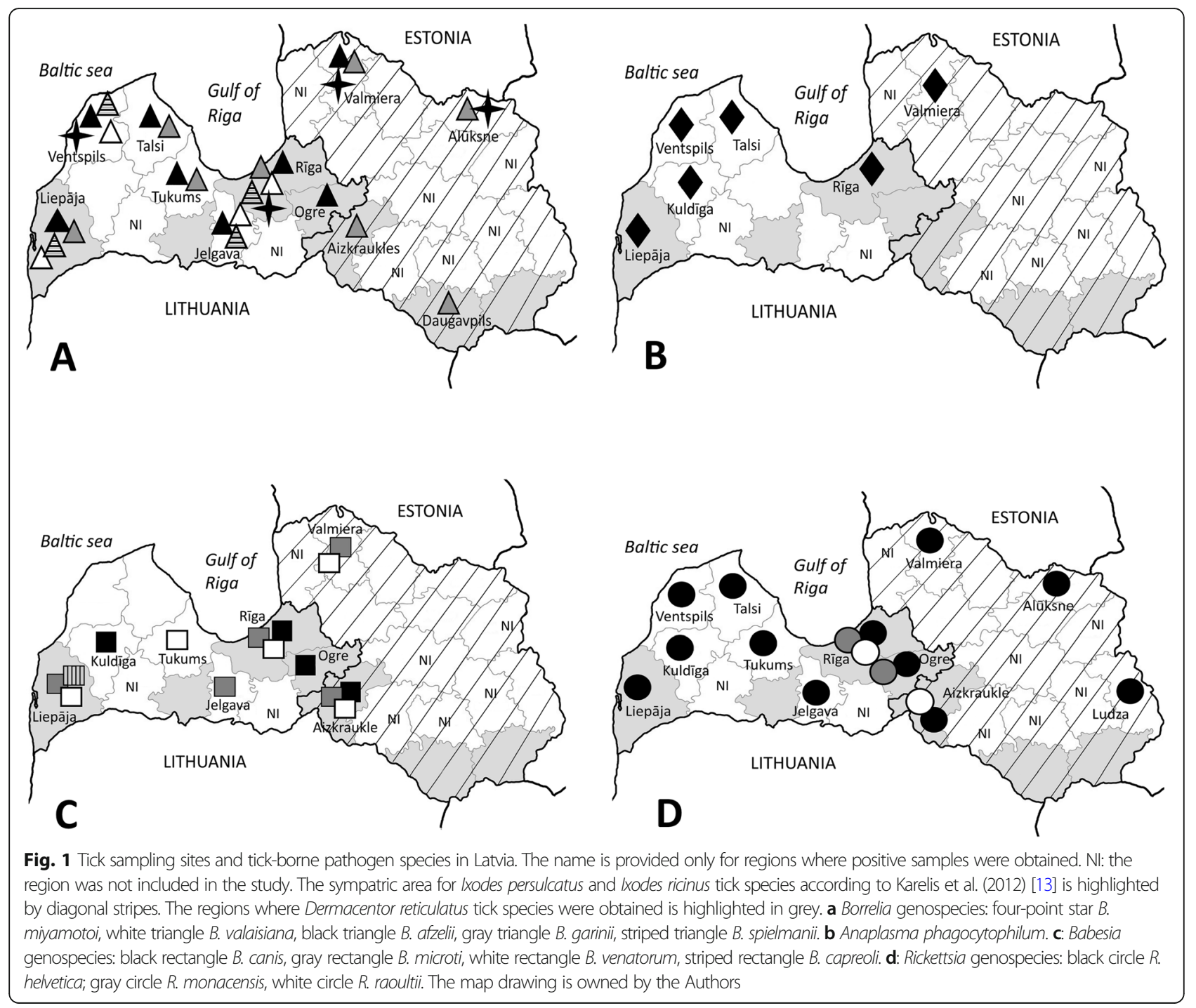

were detected (Table 2). Among I. persulcatus ticks, only $R$. helvetica-positive samples were detected; the total prevalence was $8.3 \%(2 / 24)$ (Table 2). The geographical spread of all pathogens detected in this study is presented in the Fig. 1. Our results showed that the most prevalent Borrelia species infection in I. ricinus ticks collected from dogs was B. afzelii (3.6\%) followed by B. garinii (1.7\%), B. valaisiana (1.4\%) and B. spielmanii (1.4\%). The presence of $B$. miyamotoi DNA was detected in $1.0 \%(6 / 581)$, and A. phagocytophilum - in $6.0 \%(35 / 581)$ of $I$. ricinus samples.

In total, $14.8 \%(4 / 27)$ of $D$. reticulatus ticks were Babesia-positive in our study compared with 4.0\% (23/581) of I. ricinus samples. Among I. ricinus, four Babesia species were detected: $B$. microti (1.6\%), B. venatorum (1.2\%), $B$. capreoli (0.2\%) and B. canis (1.0\%). By contrast, all Babesia in $D$. reticulatus samples were $B$. canis, and the total prevalence of $B$. canis in Dermacentor ticks was significantly higher than in I. ricinus ticks $(14.8 \%$ vs $1 \%$; $P \leq 0.05$ ).

Almost one quarter of all $I$. ricinus ticks removed from dogs were Rickettsia-positive $(24.3 \%, 141 / 581)$; the vast majority of these samples were $R$. helvetica $(23.6 \%, 137 /$ 581 ), and only few samples belonged to $R$. monacensis $(0.5 \%, 3 / 581)$ and $R$. raoultii $(0.2 \%, 1 / 581)$ (Table 2$)$. Among D. reticulatus, 11.1\% (3/27) were Rickettsia-positive, and $R$. raoultii was the sole species detected. When the prevalence of Rickettsia was compared between $I$. ricinus and $D$. reticulatus ticks, the difference was statistically significant for $R$. helvetica and $R$. raoultii species $(P \leq 0.05)$ (Table 2).

A co-infection with two and three tick-borne pathogens, including two genotypes of $B$. burgdorferi s.l. group, was detected in $7.9 \%(46 / 581)$ and $7.4 \%(2 / 27)$ of I. ricinus and $D$. reticulatus samples, respectively. In total, 19 different pathogen combinations were detected, 
Table 2 Prevalence of pathogens in ticks from domestic dogs in Latvia

\begin{tabular}{|c|c|c|c|c|}
\hline \multirow[t]{2}{*}{ Pathogen species* } & \multicolumn{4}{|l|}{ Tick species } \\
\hline & $\begin{array}{l}\text { I. ricinus } \\
(95 \% \mathrm{Cl})\end{array}$ & $\begin{array}{l}\text { I. persulcatus } \\
(95 \% \mathrm{Cl})\end{array}$ & $\begin{array}{l}\text { D. reticulatus } \\
(95 \% \mathrm{Cl})\end{array}$ & $\begin{array}{l}\text { Total } \\
(95 \% \mathrm{Cl})\end{array}$ \\
\hline Borrelia burgdorferi s.l. group, total & $10.7(8.4-13.46)$ & $0(0-16.31)$ & $0(0-14.76)$ & $9.8(7.72-12.39)$ \\
\hline B. garinii & $1.7(0.89-3.18)$ & $0(0-16.31)$ & $0(0-14.76)$ & $1.6(0.82-2.93)$ \\
\hline B. afzelii & $3.6(2.35-5.49)$ & $0(0-16.31)$ & $0(0-14.76)$ & $3.3(2.16-5.05)$ \\
\hline B. valaisiana & $1.4(0.65-2.74)$ & $0(0-16.31)$ & $0(0-14.76)$ & $1.3(0.6-2.52)$ \\
\hline B. spielmanii & $1.4(0.65-2.74)$ & $0(0-16.31)$ & $0(0-14.76)$ & $1.3(0.6-2.52)$ \\
\hline B. burgdorferi s. I. group, mix of two genotypes & $2.6(1.53-4.25)$ & $0(0-16.31)$ & $0(0-14.76)$ & $2.4(1.41-3.91)$ \\
\hline Borrelia miyamotoi & $1.0(0.42-2.29)$ & $0(0-16.31)$ & $0(0-14.76)$ & $1.0(0.38-2.11)$ \\
\hline A. phagocytophilum & $6.0(4.34-8.28)$ & $0(0-16.31)$ & $0(0-14.76)$ & $5.5(3.99-7.62)$ \\
\hline Babesia, total & $4.0(2.62-5.90$ & $0(0-16.31)$ & $14.8(5.3-33.1)$ & $4.3(2.93-6.17)$ \\
\hline B. canis & $1.0(0.42-2.29) \dagger$ & $0(0-16.31)$ & $14.8(5.3-33.1)$ & $1.6(0.82-2.93)$ \\
\hline B. microti & $1.6(0.77-2.96)$ & $0(0-16.31)$ & $0(0-14.76)$ & $1.4(0.71-2.73)$ \\
\hline B. venatorum & $1.2(0.53-2.52)$ & $0(0-16.31)$ & $0(0-14.76)$ & $1.1(0.49-2.32)$ \\
\hline B. capreoli & $0.2(0.01-1.07)$ & $0(0-16.31)$ & $0(0-14.76)$ & $0.2(0.01-0.98)$ \\
\hline Rickettsia, total & $24.3(20.95-27.92)$ & $8.3(1.16-27.0)$ & $11.1(3.03-28.88)$ & $23.1(19.98-26.55)$ \\
\hline R. helvetica & $23.6(20.3-27.2) \dagger$ & $8.3(1.16-27.0$ & $0(0-14.76) \dagger$ & $22.0(18.93-25.39)$ \\
\hline R. monacensis & $0.5(0.1-1.58)$ & $0(0-16.31)$ & $0(0-14.76)$ & $0.5(0.09-1.46)$ \\
\hline R. raoultii & $0.2(0.01-1.07) \dagger$ & $0(0-16.31)$ & $11.1(3.03-28.88) \dagger$ & $0.6(0.18-1.68)$ \\
\hline Ticks analysed & 581 & 24 & 27 & 632 \\
\hline
\end{tabular}

* Including coinfections

† Prevalences with different indices which are significantly different with $P$ values $\leq 0.05$ are indicated in bold. $P$ values were corrected for multiple testing by Holm correction

and the composition of these co-infections mirrored the pathogens' spectra as the sole co-infection found in $D$. reticulatus ticks was a combination of $B$. canis and $R$. raoultii (Table 3).

\section{Discussion}

Apart from the concerns about human health, there is an increasing interest in monitoring of canine tick-borne diseases, and how the eco-epidemiological patterns of the spread of ticks and pathogens change through time. This study aimed to investigate the prevalence of the pathogen species in ticks removed from dogs in Latvia and to analyze any possible changes between years 2011 and 2016. The results showed that, in our settings, monitoring at time points six years apart was not sufficient to observe any significant changes in the prevalence rate of the tick-borne pathogens, which have been circulating in the environment for a long time, and/or for already established loci. These results indicate the relative stability of the environmental processes. Similar results were obtained in a French study where no evidence was observed for a climate-associated increase in infection risk over the 7-year period [14]. However, during the last decade, the spread of $D$. reticulatus has been notable in several European countries, including Latvia and neighboring Lithuania [12, 15]. In this study, almost $7 \%$ of ticks removed from dogs in 2016 were D. reticulatus comparing to none in 2011, and the difference was statistically significant. This result is in accordance with previous observations: while no Dermacentor ticks were collected by flagging in years 2005-2007 in Latvian regions, new localities with $D$. reticulatus occurrence have been found in southern Latvia in the years 2013-2014 $[12,16]$. Moreover, our study demonstrated that, until the year 2016, the spreading of $D$. reticulatus ticks occurred further to the north than previously reported up to the Gulf of Riga (Fig. 1). Climate is probably the major driver to the presence or absence of a tick species in a given territory [17]. Indeed, the mean annual air temperature in Latvia in years $2011-2016$ was $0.2-1.9^{\circ} \mathrm{C}$ higher than the usual average $+5.9^{\circ} \mathrm{C}$, while the mean annual precipitation fluctuated (Fig. 2; Data source: Latvian Environment, Geology and Meteorology Centre, https://www.meteo.lv/en/). Importantly, the mean air temperature in the Baltic States including Latvia is increasing fastest in winter and spring, and decrease in the snow cover duration during the 1961-2015 period. In addition, a change of the type of winters after 1989 with a later snow cover formation and earlier snowmelt was observed for this area [18]. Thus, while various biotic and abiotic variables influencing overall $D$. reticulatus tick abundance have been reported [19], it could be 
Table 3 Prevalence of co-infections detected in ticks from domestic dogs in Latvia

\begin{tabular}{|c|c|c|c|c|}
\hline & Tick species & & & \\
\hline & $\begin{array}{l}\text { I. ricinus } \\
(95 \% \mathrm{Cl})\end{array}$ & $\begin{array}{l}\text { I. persulcatus } \\
(95 \% \mathrm{Cl})\end{array}$ & $\begin{array}{l}\text { D. reticulatus } \\
(95 \% \mathrm{Cl})\end{array}$ & $\begin{array}{l}\text { Total } \\
(95 \% \text { Cl) }\end{array}$ \\
\hline No. of samples analysed & 581 & 24 & 27 & 632 \\
\hline B. garinii two genotypes & $0.2(0.01-1.07)$ & $0(0-16.31)$ & $0(0-14.76)$ & $0.2(0.01-0.98)$ \\
\hline B. valaisiana two genotypes & $0.2(0.01-1.07)$ & $0(0-16.31)$ & $0(0-14.76)$ & $0.2(0.01-0.98)$ \\
\hline B. valaisiana + B. spielmanii & $1.6(0.77-2.96)$ & $0(0-16.31)$ & $0(0-14.76)$ & $1.4(0.71-2.73)$ \\
\hline B. afzelii $+B$. venatorum & $0.2(0.01-1.07)$ & $0(0-16.31)$ & $0(0-14.76)$ & $0.2(0.01-0.98)$ \\
\hline B. afzelii + B. microti & $0.2(0.01-1.07)$ & $0(0-16.31)$ & $0(0-14.76)$ & $0.2(0.01-0.98)$ \\
\hline B. afzelii $+R$. helvetica & $1.0(0.42-2.29)$ & $0(0-16.31)$ & $0(0-14.76)$ & $1.0(0.38-2.11)$ \\
\hline B. spielmanii $+R$. helvetica & $0.3(0.01-1.33)$ & $0(0-16.31)$ & $0(0-14.76)$ & $0.3(0.01-1.23)$ \\
\hline B. valaisiana $+R$. helvetica & $0.5(0.10-1.58)$ & $0(0-16.31)$ & $0(0-14.76)$ & $0.5(0.09-1.46)$ \\
\hline B. miyamotoi $+R$. helvetica & $0.2(0.01-1.07)$ & $0(0-16.31)$ & $0(0-14.76)$ & $0.2(0.01-0.98)$ \\
\hline A. phagocytophilum $+R$. helvetica & $1.2(0.53-2.52)$ & $0(0-16.31)$ & $0(0-14.76)$ & $1.1(0.49-2.32)$ \\
\hline A. phagocytophilum + B. capreoli & $0.2(0.01-1.07)$ & $0(0-16.31)$ & $0(0-14.76)$ & $0.2(0.01-0.98)$ \\
\hline B. microti $+R$. helvetica & $0.5(0.10-1.58)$ & $0(0-16.31)$ & $0(0-14.76)$ & $0.5(0.09-1.46)$ \\
\hline B. canis $+R$. raoultii & $0(0-0.79)$ & $0(0-16.31)$ & $7.4(0.96-24.47)$ & $0.3(0.01-1.23)$ \\
\hline B. canis $+R$. monacensis & $0.2(0.01-1.07)$ & $0(0-16.31)$ & $0(0-14.76)$ & $0.2(0.01-0.98)$ \\
\hline B. $s p$. venatorum $+R$. helvetica & $0.3(0.01-1.33)$ & $0(0-16.31)$ & $0(0-14.76)$ & $0.3(0.01-1.23)$ \\
\hline B. spielmanii $+B$. valaisiana $+R$. helvetica & $0.7(0.2-1.82)$ & $0(0-16.31)$ & $0(0-14.76)$ & $0.6(0.18-1.68)$ \\
\hline B. afzelii + A. phagocytophilum $+R$. helvetica & $0.2(0.01-1.07)$ & $0(0-16.31)$ & $0(0-14.76)$ & $0.2(0.01-0.98)$ \\
\hline B. garinii + A. phagocytophilum $+R$. helvetica & $0.2(0.01-1.07)$ & $0(0-16.31)$ & $0(0-14.76)$ & $0.2(0.01-0.98)$ \\
\hline B. afzelii + B. microti $+R$. helvetica & $0.2(0.01-1.07)$ & $0(0-16.31)$ & $0(0-14.76)$ & $0.2(0.01-0.98)$ \\
\hline Coinfections TOTAL & $7.9(5.97-10.42)$ & $0(0-16.31)$ & $7.4(0.96-24.47)$ & $7.6(5.76-9.94)$ \\
\hline
\end{tabular}

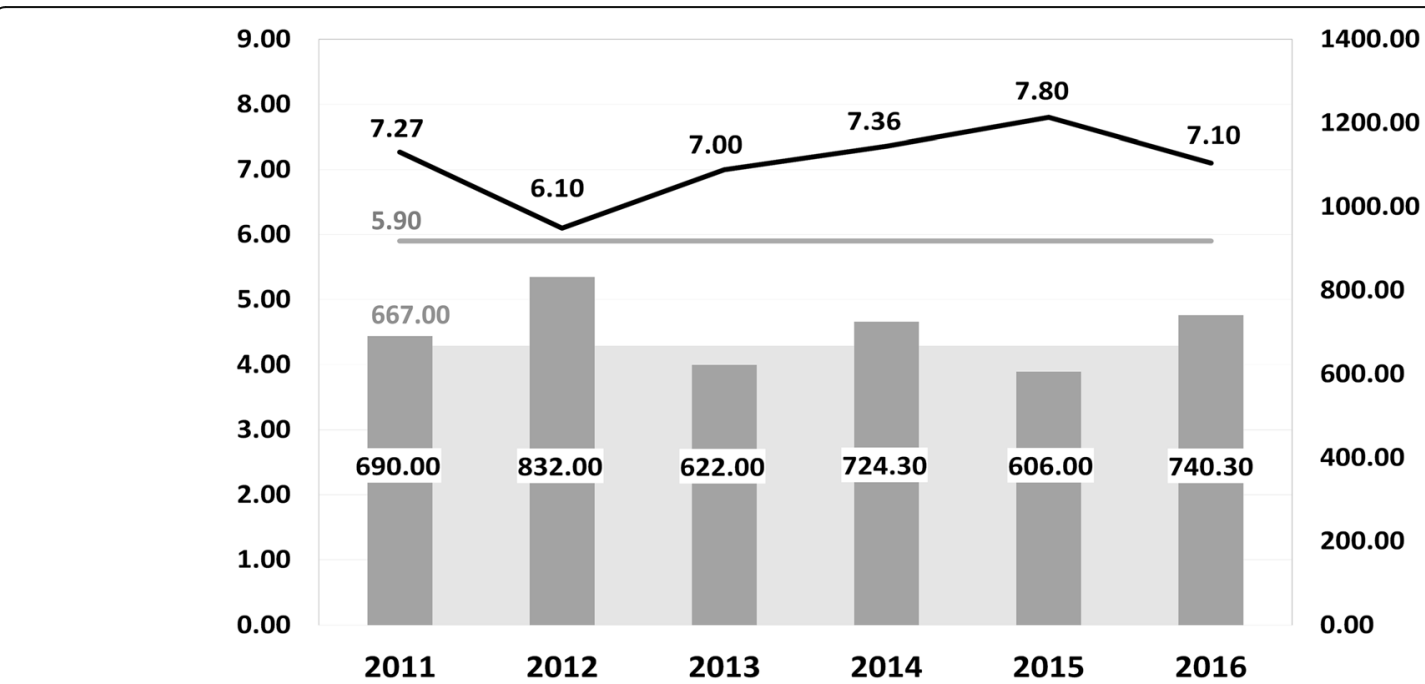

Fig. 2 Annual air temperature and precipitation trends in Latvia, 2011-2016. Data source: Latvian Environment, Geology and Meteorology Centre, https:/www.meteo.lv/en/. Gray area: the usual average annual precipitation; dark gray columns: the mean annual precipitation; gray line: the usual average annual air temperature; black line: the mean annual air temperature 
proposed that climate change supported the emergence of $D$. reticulatus foci in Latvia.

Further, 13 tick-borne human and canine pathogens were detected in ticks removed from dogs this study. In total, 35.8 and $40.0 \%$ of ticks were pathogen-positive in 2011 and 2016, respectively; this difference was not statistically significant. The spectrum of detected pathogens was compatible to those reported recently in dogassociated ticks collected in Germany, Italy, Belgium and Poland [20-23].

The most prevalent pathogen genus was Rickettsia, it was detected in $24.3 \%$ of I. ricinus, $8.3 \%$ of I. persulcatus and $11.1 \%$ of D. reticulatus ticks. Interestingly, in studies of pet-associated ticks, Rickettsia spp. was detected in 18.4 and $14.1 \%$ of Ixodes ticks in Italy and Belgium, respectively, while over $50 \%$ of $I$. ricinus were positive for Rickettsia spp. in Poland and Germany; also, Dermacentor ticks were pathogen-negative in Belgium, but $39 \%$ of D. reticulatus were found to be Rickettsia-positive in the study in Germany [20-23]. Such non-uniform prevalence of pathogens could be related to many variables including, among others, existence of natural foci, tick and host abundance, sampling area and sampling season. For example, large differences in pathogen frequencies in questing Dermacentor ticks (31.4-78.3\%) were observed between sampling sites in Germany [19]. However, methodology-related factors such as the level of tick engorgement, feeding on an infected animal and sensitivity of the methods used should also be considered.

In our study, three Rickettsia species were identified: $R$. helvetica, $R$. monacensis and $R$. raoultii. R. helvetica has been isolated from Ixodes ticks in many European and Asian countries, however, its pathogenicity is relatively unknown. While there is some evidence that it may cause disease in humans [24], there are no such reports regarding clinical cases in dogs. On the other hand, $R$. monacensis is recognized as an emerging human pathogen, as cases of infection in humans were reported in Spain, Italy, the Netherlands and South Korea [25]. $R$. monacensis was also identified in a blood sample of a dog (0.7\%) in Maio Island, Cape Verde archipelago, however, its pathogenicity in animals is still unknown [26]. $R$. raoultii is frequently detected in multiple tick species and, along with $R$. slovaca, is a causative agent of a syndrome in humans known as DEBONEL/TIBOLA (Dermacentor-borne necrosis erythema and lymphadenopathy/Tick-borne lymphadenopathy) [27]. It is a newly recognized emerging disease, as its incidence has been increasing in Europe during the last decade [28]. Clinical cases in animals induced by $R$. raoultii have not been described so far, however, in dogs in Germany $R$. raoultii DNA was detected in $0.68 \%$ of samples and a seroprevalence of $2.8 \%$ was reported $[29,30]$.
A. phagocytophilum is the etiologic agent for Human Granulocytic Anaplasmosis (HGA), which occurs in America, Europe and Asia [31]. There are reports on granulocytic anaplasmosis in a variety of domestic and wild animal species including dogs, cats, horses and cattle [32]. The main vector in Europe is I. ricinus, however, A. phagocytophilum has been detected in questing ticks of many species including $D$. reticulatus and $I$. persulcatus, and the overall infection rate of I.ricinus ticks in Europe varied from $0.4 \%$ to even $33.9 \%$ in some localities (reviewed in [32]). Seroprevalence studies in European dogs indicated that 3 to $57 \%$ of dogs carried $A$. phagocytophilum [33], while in Latvia, A. phagocytophilum seroprevalence in dogs was significantly higher in the $I$. ricinus region than in the $I$. persulcatus region $(12.5 \%$ vs $2 \%)$ [34]. In the present study, $6 \%$ of $I$. ricinus ticks removed from dogs were $A$. phagocytophilum-positive, confirming risks present for humans and animals.

In $I$. ricinus, a member of the relapsing fever group spirochete $B$. miyamotoi, as well as Lyme-disease borrelia $B$. afzelii, B. garinii, B. valaisiana, B. spielmanii were present, but no Borrelia-positive $D$. reticulatus ticks were detected in our study. While these pathogens are of a high importance to human health, studies in Europe have shown that many dogs are exposed to Borrelia, but only a small number of seropositive animals ever have a clinical disease (reviewed in [35]). According to the American College of Veterinary Internal Medicine consensus update on Lyme borreliosis in dogs and cats it is stated that in dogs residing in North America Lyme borreliosis is associated only with $B$. burgdorferi sensu stricto, and it has not yet been proven that borrelia found in Europe can cause clinical signs in dogs [36]. Nevertheless, for the future reference and from a standpoint of the OneHealth perspective it is important to find out, which borrelia species are prevalent in ticks removed from animals.

Among Babesia, B. microti, B. venatorum, B. capreoli and $B$. canis were detected in this study. Both $B$. microti and $B$. venatorum are considered to pose a zoonotic risk to humans, but no reports exist that they either infect or cause disease in dogs. On the other hand, $1.6 \%$ of ticks carried B. canis, the agent of canine babesiosis. Importantly, none $B$. canis-positive field-collected ticks were detected in Latvia in the 2005-2007 time frame, while the first autochthonous canine babesiosis cases in the country were reported between years 2009 and 2011, and $B$. canis was detected in D. reticulatus ticks in Latvia in the 2013-2015 time frame [11, 16, 37]. Unsurprisingly, in this study, the prevalence of B. canis in D. reticulatus was significantly higher than in $I$. ricinus ticks $(14.8 \%$ vs $1 \% ; P \leq 0.05)$. The presence of $B$. canis in $I$. ricinus observed here is in accordance with the study of Cieniuch and colleagues [38] in Poland, which found out 
that around 1\% of field-collected I. ricinus ticks were infected, and may explain the cases of autochthonous canine babesiosis in Latvia in 2009-2011, when Dermacentor ticks were apparently absent in the country [11]. However, future studies are needed to confirm the role of this tick species. On the other hand, a possibility of a cross-infection exists, when multiple ticks, including infected $D$. reticulatus, are feeding on one animal, or if the dog itself is a carrier of the disease.

While most people in Latvia are aware of human tickborne diseases, information to the general public on the same topic in house-hold pets is insufficient in Latvia, leading to common misconceptions such "my dog/cat is exposed to ticks so frequently that it is immune to them" (Seleznova M., personal communication). This lack of awareness also means that a lot of pet owners disregard regular anti-tick treatments to their animals during the active season as unnecessary. This situation was exacerbated during the last decade because of the speedy spreading of $D$. reticulatus, which were previously absent in the country, and the risk of infection arising from this tick species populations is not sufficiently investigated. The results of this study confirmed that the spread of novel vectors could bring additional risk of exposure to novel emerging pathogens to pets and their owners, as both $B$. canis and $R$. raoultii were shown to be highly associated with $D$. reticulatus ticks. In addition, the clear possibility of dog's infestation with several ticks in the sympatric areas for Ixodes and Dermacentor tick species increases the probability of the coinfection with several pathogens, which, in turn, could increase the risk of severe pathology, and complicates both, diagnosis and therapy. Infection with tick-borne pathogens can also be complicated by other arthropodborne diseases that share the tick biohabitat, and coinfection could partially explain variations in clinical presentation, pathogenicity and response to therapy in dogs [10].

In this study, a co-infection with two and three tickborne pathogens was detected in 7.9 and $7.4 \%$ of I. ricinus and $D$. reticulatus samples, respectively, and a high variability of co-infections was observed. In total, 19 different pathogen combinations were detected among the samples, none of which appeared to be a dominant pattern. This result indicates that a substantial risk of the co-infection with multiple tick-borne pathogens exists, and the combination of pathogens appears to be a dynamic process which varies depending on the changes in the prevalence of separate pathogens in nature. Thus the awareness regarding possible co-infections in ticks should be increased and further studies are needed, especially against the background of the climate change, the emergence and the spread of the sympatric areas for Ixodes and Dermacentor tick species, and increasing importance of pet travel.
Several limitations of this study should be outlined. First, only adult ticks were included in this study. While the removal of the adult ticks from animals is relatively easy, the molecular analysis of nymphs could provide additional important data. Secondly, the ticks were collected from dogs and were partially or fully engorged. Thus, a possibility exists that some tick samples were pathogen-positive because of feeding on a positive dog. Also, the number of $I$. persulcatus ticks available for this study was very low and did not mirror the actual spread of this tick species in Latvia (according to data presented in $[16,34,39]$. Only $R$. helvetica was identified in these samples, however, the presence of different pathogens in the field-collected I. persulcatus ticks such as Babesia, Borrelia and Ehrlichia have been shown previously in Latvia.

\section{Conclusions}

In conclusion, the results of this study clearly demonstrate the potential danger from the inadvertent introduction of novel disease pathogens and vectors in Latvia. A substantial risk of the co-infection with multiple tickborne pathogens in dogs exists, and the combination of pathogens appears to be a dynamic process which varies depending on the changes in the prevalence of separate pathogens in nature. Further evaluation of the role of $D$. reticulatus as a vector of pathogens to humans and animals is required, and awareness of tick-borne disease caused by $R$. raoultii and B. canis needs to be increased in human and veterinary medicine.

\section{Methods}

\section{Samples collection}

Tick samples were collected from dogs in different regions of Latvia in years 2011 and 2016. Only adult ticks were included in this study. We calculated the intensity of the infestation as the mean number of ticks per infested host.

Ticks were removed by veterinarians during the routine visit, preserved in 70\% ethanol and stored individually at $-20^{\circ} \mathrm{C}$ after morphological identification [40].

\section{DNA isolation}

Ticks were washed with $70 \%$ ethanol, dried, transferred into individual tubes and crushed in $300 \mu \mathrm{l}$ of sterile water. $50 \mu \mathrm{l}$ of digestion buffer $[30 \mathrm{mM}$ Tris- $\mathrm{HCl}(\mathrm{pH}$ 8.0), $75 \mathrm{mM}$ EDTA (pH 8.0), $0.3 \mathrm{M} \mathrm{NaCl}, 1.5 \% \mathrm{SDS}$ ] and $2.5 \mu \mathrm{l}$ of proteinase $\mathrm{K}(20 \mathrm{mg} / \mathrm{ml})$ were added to $100 \mu \mathrm{l}$ of tick suspension, and the mixture was incubated at $50^{\circ} \mathrm{C}$ for $1 \mathrm{~h}$. DNA was extracted by phenol/chloroform method and stored at $-20^{\circ} \mathrm{C}$.

\section{Differentiation of Ixodes tick species}

All Ixodes tick samples were analyzed by using real-time PCR method as described elsewhere [41]. 


\section{Detection of tick-borne pathogens}

All samples were tested for the presence of Babesia sp., Borrelia sp., A. phagocytophilum and Rickettsia sp. using nested polymerase chain reaction (PCR) that targeted $18 S$ rRNA, $16 S$ rRNA, $16 S$ rRNA and gltA gene, respectively. All primers are listed in Table 4. The PCR reagents were purchased from Thermo Fisher Scientific, USA. All PCR reactions were performed in a final volume of $26 \mu \mathrm{l}$, containing $1 \mathrm{x}$ Taq Buffer with $\left(\mathrm{NH}_{4}\right)_{2} \mathrm{SO}_{4}, 2.5 \mathrm{mM}$ $\mathrm{MgCl}_{2}, 100 \mu \mathrm{M}$ of each dNTPs, $0.2 \mu \mathrm{M}$ of each primer, $0.8 \mathrm{U}$ of Taq DNA polymerase (recombinant) and $2 \mu \mathrm{l}$ of DNA template. Further, $2 \mu \mathrm{l}$ of the PCR product from the first reaction was used as a template for nested PCR.

The PCR assays for Babesia sp. detection were performed under the following conditions: an initial denaturation at $95^{\circ} \mathrm{C}$ for $3 \mathrm{~min} ; 35$ cycles of denaturation at $95^{\circ} \mathrm{C}$ for $20 \mathrm{~s}$, primer annealing at $55^{\circ} \mathrm{C}$ for $30 \mathrm{~s}$, and elongation at $72{ }^{\circ} \mathrm{C}$ for $1 \mathrm{~min}$; and a final elongation step at $72{ }^{\circ} \mathrm{C}$ for $5 \mathrm{~min}$. Nested PCR assays were performed under the same conditions, but with reduced time (30 s) for the elongation step. This assay was Babesia-and Theileria-specific. The PCR assays for Borrelia sp. detection were performed under the following conditions: an initial denaturation at $95^{\circ} \mathrm{C}$ for $3 \mathrm{~min}$; 30 cycles of denaturation at $95^{\circ} \mathrm{C}$ for $20 \mathrm{~s}$, primer annealing at $63^{\circ} \mathrm{C}$ for $20 \mathrm{~s}$, and elongation at $72{ }^{\circ} \mathrm{C}$ for $40 \mathrm{~s}$; and a final elongation step at $72{ }^{\circ} \mathrm{C}$ for $5 \mathrm{~min}$. Nested PCR assays were performed under the following conditions: an initial denaturation at $95^{\circ} \mathrm{C}$ for $3 \mathrm{~min} ; 35$ cycles of denaturation at $95^{\circ} \mathrm{C}$ for $20 \mathrm{~s}$, primer annealing at $56^{\circ} \mathrm{C}$ for $20 \mathrm{~s}$, and elongation at $72{ }^{\circ} \mathrm{C}$ for $30 \mathrm{~s}$; and a final elongation step at $72{ }^{\circ} \mathrm{C}$ for $5 \mathrm{~min}$. The PCR assays for $A$. phagocytophilum detection were performed under the following conditions: an initial denaturation at $95^{\circ} \mathrm{C}$ for $3 \mathrm{~min} ; 35$ cycles of denaturation at $95^{\circ} \mathrm{C}$ for $20 \mathrm{~s}$, primer annealing at $58{ }^{\circ} \mathrm{C}$ for $20 \mathrm{~s}$, and elongation at $72{ }^{\circ} \mathrm{C}$ for $40 \mathrm{~s}$; and a final elongation step at $72{ }^{\circ} \mathrm{C}$ for $5 \mathrm{~min}$. Nested PCR assays were performed under the same conditions, but reduced to 30 cycles and a reduced time $(30 \mathrm{~s})$ in the elongation step was used. The PCR assays for Rickettsia sp. detection were performed under the following conditions: an initial denaturation at $95^{\circ} \mathrm{C}$ for $3 \mathrm{~min} ; 35$ cycles of denaturation at $95^{\circ} \mathrm{C}$ for $20 \mathrm{~s}$, primer annealing at $55^{\circ} \mathrm{C}$ for $30 \mathrm{~s}$, and elongation at $72^{\circ} \mathrm{C}$ for $90 \mathrm{~s}$; and a final elongation step at $72^{\circ} \mathrm{C}$ for $5 \mathrm{~min}$. Nested PCR assays were performed under the same conditions, but a reduced time $(20 \mathrm{~s})$ in the denaturation step was used. As positive controls, plasmids with inserts derived from B. canis, B. afzelii ACAI strain, A. phagocytophilum Webster strain and $R$. raoultii were used, respectively. Positive and negative controls were included in all PCR amplification.

Amplicons were purified and analyzed by Sanger sequencing on both DNA strands using an ABI Prism 3100 Genetic Analyzer (PerkinElmer, Waltham, MA, USA). Pathogens were identified using the GenBank database. Pathogen genotypes were assigned based on sequence similarity $(99-100 \%)$ to the corresponding gene of the reference strains (GenBank accession numbers: B. afzelii NR_104748.1; B. garinii NR_043413.1; $B$. spielmanii NR_104871.1; B. valaisiana NR_036807.1; $B$. miyamotoi NR_025861.1; B. microti XR_001160977.2; $B$.

Table 4 Primers used in this study

\begin{tabular}{|c|c|c|c|c|}
\hline Pathogen/target gene & Primer & Sequence $\left(5^{\prime}-3^{\prime}\right)$ & Amplicon size, bp ${ }^{a}$ & Reference \\
\hline \multirow[t]{4}{*}{ Borrelia spp./ 16S rRNA } & $16 S 1 \mathrm{~A}$ & CTAACGCTGGCAGTGCGTCTTAAGC & 724 & {$[42]$} \\
\hline & 16S1B & AGCGTCAGTCTTGACCCAGAAGTTC & & [42] \\
\hline & $16 S 2 A$ & AGTCAAACGGGATGTAGCAATACA & 657 & [42] \\
\hline & $16 S 2 B$ & GGTATTCTITCTGATATCAACAG & & [42] \\
\hline \multirow[t]{4}{*}{ A. phagocytophilum/ 165 rRNA } & ge3a & CACATGCAAGTCGAACGGATTATTC & 932 & [43] \\
\hline & ge10r & TTCCGTTAAGAAGGATCTAATCTCC & & [43] \\
\hline & gegf & AACGGATTATTCTTTATAGCTTGCT & 546 & [43] \\
\hline & ge2 & GGCAGTATTAAAAGCAGCTCCAG & & [43] \\
\hline \multirow[t]{4}{*}{ Rickettsia sp./ gltA } & VC29 & GCGGAAGCCGATTGCTTTAC & $1108-1111$ & This study \\
\hline & CS-1069 & GAGGGTCTTCGTGCATTTCTT & & [44] \\
\hline & $\mathrm{RH} 314$ & AAACAGGTTGCTCATCATTC & $898-901$ & [45] \\
\hline & CS-1069 & GAGGGTCTTCGTGCATTTCTT & & [44] \\
\hline \multirow[t]{4}{*}{ Babesia spp./ 18S rRNA } & $5-22 \mathrm{~F}$ & GTTGATCCTGCCAGTAGT & $1622-1731$ & [46] \\
\hline & $1661 \mathrm{R}$ & AACCTTGTTACGACTTCTC & & [46] \\
\hline & $455-479 F$ & GTCTTGTAATTGGAATGATGGTGAC & $310-368$ & [46] \\
\hline & 793-772R & ATGCCCCCAACCGTTCCTATTA & & [46] \\
\hline
\end{tabular}

${ }^{a}$ Amplicon size depends on the pathogen genospecies, $b p$ base pairs 
canis AY072926.1; B. venatorum AY046575.1; B. capreoli FJ944827.1; $R$. raoultii NZ_CP019435.1; $R$. helvetica NZ_CM001467.1; $R$. monacensis NZ_LN794217.1. All primers and probes were synthesized by Metabion International AG, Germany, and all PCR reagents were purchased from ThermoScientific, Waltham, MA, USA.

\section{Statistical analysis}

All ticks were processed individually, and the prevalence was expressed as a percentage. A $P$ value was calculated using the two-sided Fisher's exact test (GraphPad Prism 6, GraphPad Software, La Jolla, CA, USA). Values of $P \leq$ 0.05 were considered significant. The mean intensities of tick infestation of dogs between years were compared by the Mann-Whitney U test (MedCalc Software, Version 19.1). Prevalence of pathogens was calculated with $95 \%$ confidence intervals of a proportion by the "exact" method of Clopper and Pearson (GraphPad Prism 6). P values were adjusted for the multiple testing by Holm correction in R using the R Statistical Package.

\section{Abbreviations}

dNTP: Deoxyribonucleotide triphosphate; EDTA: Ethylenediaminetetraacetic acid; PCR: Polymerase chain reaction; SDS: Sodium dodecyl sulfate

\section{Acknowledgements}

Authors are thankful to all veterinarians and pet owners for collecting and providing tick samples.

\section{Authors' contributions}

VC, IB, RR - planned the study, IB, MS - managed the sample collection, AN, $V C, M S, R K, D A, A K, S A, M L$ performed DNA extraction, $P C R$, real-time PCR, sequencing and analysis, MS, RR wrote the manuscript. All authors commented on the manuscript, read and approved the final version.

\section{Funding}

This work was supported by the ERDF project Nr. 1.1.1.1/16/A/044. The funders had no role in study design, data collection, analysis and interpretation, decision to publish, or preparation of the manuscript.

\section{Availability of data and materials}

The datasets used and/or analysed during the current study are available from the corresponding author on reasonable request.

\section{Ethics approval and consent to participate}

Not applicable.

\section{Consent for publication}

Not applicable.

\section{Competing interests}

The authors declare that they have no competing interests.

\section{Author details}

'Latvian Biomedical Research and Study Centre, Ratsupites Str. 1, Riga

LV-1067, Latvia. ${ }^{2}$ Latvia University of Agriculture, Jelgava, Latvia.

Received: 9 June 2019 Accepted: 21 October 2019

Published online: 06 November 2019

\section{References}

1. de la Fuente J, Antunes S, Bonnet S, Cabezas-Cruz A, Domingos AG, EstradaPeña A, et al. Tick-pathogen interactions and vector competence: identification of molecular drivers for tick-borne diseases. Front Cell Infect Microbiol. 2017;7:114.
2. Dantas-Torres F. The brown dog tick, Rhipicephalus sanguineus (Latreille, 1806) (Acari: Ixodidae): from taxonomy to control. Vet Parasitol. 2008;152: $173-85$

3. Solano-Gallego L, Baneth G. Babesiosis in dogs and cats - expanding parasitological and clinical spectra. Vet Parasitol. 2011;181:48-60.

4. Földvári G, Široký P, Szekeres S, Majoros G, Sprong H. Dermacentor reticulatus: a vector on the rise. Parasit Vectors. 2016;9(1):314.

5. Rizzoli A, Silaghi C, Obiegala A, Rudolf I, Hubálek Z, Földvári G, et al. Ixodes ricinus and its transmitted pathogens in urban and peri-urban areas in Europe: new hazards and relevance for public health. Front Public Health. 2014;2:251.

6. Alekseev AN, Dubinina HV, Jushkova OV. First report on the coexistence and compatibility of seven tick-borne pathogens in unfed adult Ixodes persulcatus Schulze (Acarina: Ixodidae). Int J Med Microbiol. 2004;293(Suppl 37):104-8.

7. Kjær LJ, Soleng A, Edgar KS, Lindstedt HEH, Paulsen KM, Andreassen ÅK, Korslund L, Kjelland V, Slettan A, Stuen S, Kjellander P, Christensson M, Teräväinen M, Baum A, Isbrand A, Jensen LM, Klitgaard K, Bødker R. A largescale screening for the taiga tick, lxodes persulcatus, and the meadow tick, Dermacentor reticulatus, in southern Scandinavia, 2016. Parasit Vectors. 2019 Jul 9:12(1):338.

8. Jones EH, Hinckley AF, Hook SA, Meek Jl, Backenson B, Kugeler KJ, et al. Pet ownership increases human risk of encountering ticks. Zoonoses Public Health. 2018;65(1):74-9.

9. Dantas-Torres F, Chomel BB, Otranto D. Ticks and tick-borne diseases: a one health perspective. Trends Parasitol. 2012;28(10):437-46.

10. Shaw SE, Day MJ, Birtles RJ, Breitschwerdt EB. Tick-borne infectious diseases of dogs. Trends Parasitol. 2001;17:74-80.

11. Berzina I, Capligina V, Baumanis V, Ranka R, Cirule D, Matise I. Autochthonous canine babesiosis caused by Babesia canis canis in Latvia. Vet Parasitol. 2013;196(3-4):515-8.

12. Paulauskas $A$, Radzijevskaja J, Mardosaite-Busaitiene D, Aleksandravičienie $A$ Galdikas M, Krikštolaitis R. New localities of Dermacentor reticulatus ticks in the Baltic countries. Ticks Tick Borne Dis. 2015;6(5):630-5.

13. Karelis G, Bormane A, Logina I, Lucenko I, Suna N, Krumina A, Donaghy M. Tick-borne encephalitis in Latvia 1973-2009: epidemiology, clinical features and sequelae. Eur J Neurol. 2012;19:62-8.

14. Paul RE, Cote M, Le Naour E, Bonnet SI. Environmental factors influencing tick densities over seven years in a French suburban forest. Parasit Vectors. 2016;9(1):309.

15. Mierzejewska EJ, Welc-Faleciak R, Karbowiak G, Kowalec M, Behnke JM, Bajer A. Dominance of Dermacentor reticulatus over Ixodes ricinus (Ixodidae) on livestock, companion animals and wild ruminants in eastern and Central Poland. Exp Appl Acarol. 2015;66:83-101.

16. Capligina V, Berzina I, Bormane A, Salmane I, Vilks K, Kazarina A, et al. Prevalence and phylogenetic analysis of Babesia spp. in Ixodes ricinus and Ixodes persulcatus ticks in Latvia. Exp Appl Acarol. 2016;68(3):325-36.

17. Cumming GS. (2002). Comparing climate and vegetation as limiting factors for species ranges of African ticks. Ecology. 2002;83(1):255-68.

18. Rimkus E, Briede A, Jaagus J, Stonevicius E, Kilpys J, Viru B. Snow-cover regime in Lithuania, Latvia and Estonia and its relationship to climatic and geographical factors in 1961-2015. Boreal Env Res. 2018;23:193-208.

19. Kohn M, Krücken J, McKay-Demeler J, Pachnicke S, Krieger K, von SamsonHimmelstjerna G. Dermacentor reticulatus in Berlin/Brandenburg (Germany): activity patterns and associated pathogens. Ticks Tick Borne Dis. 2019 Jan; 10(1):191-206.

20. Schreiber C, Krücken J, Beck S, Maaz D, Pachnicke S, Krieger K, Gross M, Kohn B, von Samson-Himmelstjerna G. Pathogens in ticks collected from dogs in Berlin/Brandenburg, Germany. Parasit Vectors. 2014;7:535.

21. Król N, Obiegala A, Pfeffer M, Lonc E, Kiewra D. Detection of selected pathogens in ticks collected from cats and dogs in the Wroclaw. agglomeration, South-West Poland. Parasit Vectors. 2016;9(1):351. https://doi. org/10.1186/s13071-016-1632-0.

22. Claerebout E, Losson B, Cochez C, Casaert S, Dalemans AC, De Cat A, Madder M, Saegerman C, Heyman P, Lempereur L. Ticks and associated pathogens collected from dogs and cats in Belgium. Parasit Vectors. 2013 Jun 19;6:183. https://doi.org/10.1186/1756-3305-6-183.

23. Morganti G, Gavaudan S, Canonico C, Ravagnan S, Olivieri E, Diaferia M, Marenzoni ML, Antognoni MT, Capelli G, Silaghi C, Veronesi F. Molecular survey on rickettsia spp., Anaplasma phagocytophilum, Borrelia burgdorferi Sensu Lato, and Babesia spp. in Ixodes ricinus ticks infesting dogs in Central 
Italy. Vector Borne Zoonotic Dis. 2017 Nov;17(11):743-8. https://doi.org/10. 1089/vbz.2017.2154.

24. Nilsson $\mathrm{K}$, Elfving $\mathrm{K}$, Påhlson C. Rickettsia helvetica in patient with meningitis, Sweden, 2006. Emerg Infect Dis. 2010;16(3):490-2.

25. Kim YS, Choi YJ, Lee KM, Ahn KJ, Kim HC, Klein T, et al. First isolation of rickettsia monacensis from a patient in South Korea. Microbiol Immunol. 2017;61(7):258-63.

26. Lauzi S, Maia JP, Epis S, Marcos R, Pereira C, Luzzago C, et al. Molecular detection of Anaplasma platys, Ehrlichia canis, Hepatozoon canis and rickettsia monacensis in dogs from Maio Island of Cape Verde archipelago. Ticks Tick Borne Dis. 2016;7(5):964-9.

27. Parola P, Rovery C, Rolain JM, Brouqui P, Davoust B, Raoult D. Rickettsia slovaca and R. raoultii in tick-borne Rickettsioses. Emerg Infect Dis. 2009;15(7):1105-8.

28. Portillo A, Santibáñez S, García-Álvarez L, Palomar AM, Oteo JA. Rickettsioses in Europe. Microbes Infect. 2015;17(11-12):834-8.

29. Wächter M, Wölfel S, Pfeffer M, Dobler G, Kohn B, Moritz A, et al. Serological differentiation of antibodies against rickettsia helvetica, R. raoultii, R. slovaca, R. monacensis and R. felis in dogs from Germany by a microimmunofluorescent antibody test. Parasit Vectors. 2015;8:126.

30. Liesner JM, Krücken J, Schaper R, Pachnicke S, Kohn B, Müller E, et al. Vectorborne pathogens in dogs and red foxes from the federal state of Brandenburg, Germany. Vet Parasitol. 2016;224:44-51.

31. Bakken JS, Dumler JS. Human Granulocytic Anaplasmosis. Infect Dis Clin North Am. 2015;29(2):341-55.

32. Stuen $\mathrm{S}$, Granquist EG, Silaghi C. Anaplasma phagocytophilum - a widespread multi-host pathogen with highly adaptive strategies. Front Cell Infect Microbiol. 2013;3:31.

33. Sainz Á, Roura X, Miró G, Estrada-Peña A, Kohn B, Harrus S, et al. Guideline for veterinary practitioners on canine ehrlichiosis and anaplasmosis in Europe. Parasit Vectors. 2015;8:75.

34. Berzina I, Capligina V, Bormane A, Pavulina A, Baumanis V, Ranka R, et al. Association between Anaplasma phagocytophilum seroprevalence in dogs and distribution of Ixodes ricinus and Ixodes persulcatus ticks in Latvia. Ticks Tick Borne Dis. 2013:4(1-2):83-8.

35. Pantchev N, Pluta S, Huisinga E, Nather S, Scheufelen M, Vrhovec MG, et al. Tick-borne diseases (Borreliosis, Anaplasmosis, Babesiosis) in German and Austrian dogs: status quo and review of distribution, transmission, clinical findings, diagnostics and prophylaxis. Parasitol Res. 2015;114:S19-54.

36. Littman MP, Gerber B, Goldstein RE, Labato MA, Lappin MR, Moore GE. ACVIM consensus update on Lyme borreliosis in dogs and cats. J Vet Intern Med. 2018;32(3):887-903.

37. Radzijevskaja J, Mardosaitè-Busaitienè D, Aleksandravičienè A, Paulauskas A. Investigation of Babesia spp. in sympatric populations of Dermacentor reticulatus and Ixodes ricinus ticks in Lithuania and Latvia. Ticks Tick Borne Dis. 2018;9(2):270-4.

38. Cieniuch S, Stańczak J, Ruczaj A. The first detection of Babesia EU1 and Babesia canis canis in Ixodes ricinus ticks (Acari, Ixodidae) collected in urban and rural areas in northern Poland. Pol J Microbiol. 2009;58(3):231-6.

39. Bormane A, Lucenko I, Duks A, Mavtchoutko V, Ranka R, Salmina K, et al. Vectors of tick-borne diseases and epidemiological situation in Latvia in 1993-2002. Int J Med Microbiol. 2004;293(Suppl 37):36-47.

40. Hillyard P. Ticks of North-West Europe. Shrewsbury: Field Studies Council; 1996.

41. Kovalev SY, Mukhacheva TA. An improved real-time PCR method to identify hybrids between Ixodes persulcatus and Ixodes ricinus ticks. Ticks Tick Borne Dis. 2018;9(1):37-8.

42. Richter D, Matuschka FR. Perpetuation of the Lyme disease spirochete Borrelia lusitaniae by lizards. Appl Environ Microbiol. 2006;72:4627-32.

43. Liz JS, Anderes L, Sumner JW, Massung RF, Gern L, Rutti B, et al. PCR detection of granulocytic Ehrlichiae in Ixodes ricinus ticks and wild small mammals in western Switzerland. J Clin Microbiol. 2000;38:1002-7.

44. Mcintosh D, Bezerra RA, Luz HR, Faccini JL, Gaiotto FA, Gine GA, et al. Detection of rickettsia bellii and rickettsia amblyommii in Amblyomma longirostre (Acari: Ixodidae) from Bahia state, Northeast Brazil. Braz Microbiol. 2015;46(3):879-83.

45. Nilsson $\mathrm{K}$, Lindquist O, Liu AJ, Jaenson TG, Friman G, Pahlson C. Rickettsia helvetica in Ixodes ricinus ticks in Sweden. J Clin Microbiol. 1999;37(2):400-3.

46. Birkenheuer A, Levy MG, Breitschwerdt EB. Development and evaluation of a seminested PCR for detection and differentiation of Babesia gibsoni (Asian genotype) and B. canis DNA in canine blood samples. J Clin Microbiol. 2003;41:4172-7.

\section{Publisher's Note}

Springer Nature remains neutral with regard to jurisdictional claims in published maps and institutional affiliations.

\section{Ready to submit your research? Choose BMC and benefit from}

- fast, convenient online submission

- thorough peer review by experienced researchers in your field

- rapid publication on acceptance

- support for research data, including large and complex data types

- gold Open Access which fosters wider collaboration and increased citations

- maximum visibility for your research: over $100 \mathrm{M}$ website views per year

At BMC, research is always in progress.

Learn more biomedcentral.com/submissions 